\title{
Synthesis and Characterization of Nanopore $\mathrm{Mo}^{\mathrm{VI}}$-Imprinted Polymer and Its Application as Solid Phase for Extraction, Separation and Preconcentration of Molybdenum Ions from Water Samples
}

\author{
Fatemeh Ardestani, ${ }^{a}$ Majid Haji Hosseini, ${ }^{*, b}$ Majid Taghizadeh, ${ }^{a}$ \\ Mohammad Reza Pourjavid ${ }^{b}$ and Mohammad Rezaee ${ }^{b}$ \\ ${ }^{a}$ Department of Chemical Engineering, Babol University of Technology, 484, 4714871167 Babol, \\ Iran \\ ${ }^{b}$ Nuclear Fuel Cycle Research School, Nuclear Science \& Technology Research Institute, Atomic \\ Energy Organization of Iran, 14395-836 Tehran, Iran
}

\begin{abstract}
The purpose of this study is to prepare a new ion imprinted polymer for $\mathrm{Mo}^{\mathrm{VI}}$ with high selectivity. Ion-imprinted polymer (IIP) particles were synthesized by thermally copolymerization. For the synthesis of the ion imprinted polymer, the ion pair of ( $\mathrm{Mo}^{\mathrm{VI}}$-thiocyanate) and $\mathrm{NR}_{4}{ }^{+}$was used. The ion pair was precipitated in an aqueous phase and then dissolved in acetonitrile as a porogen. The imprinted ion was removed using $10 \%$ (v/v) methanol in $\mathrm{HCl}\left(0.5 \mathrm{~mol} \mathrm{~L}^{-1}\right)$. The unleached and leached IIP particles were characterized by infrared spectroscopy, thermogravimetric analysis, surface area analysis, scanning electron microscopy and energy dispersive X-ray analysis. The use of the new $\mathrm{Mo}^{\mathrm{VI}}$-IIP in solid phase extraction revealed a maximum adsorption capacity of $3.77 \mathrm{mg} \mathrm{Mo}{ }^{\mathrm{VI}}$ per gram of $\mathrm{Mo}^{\mathrm{VI}}$-IIP in optimum conditions of extraction. The selectivity coefficients of the IIP for Mo in comparison with other metal ions were also evaluated. The proposed Mo-IIP was successfully applied for $\mathrm{Mo}^{\mathrm{VI}}$ determination in different types of water samples.
\end{abstract}

Keywords: ion imprinted polymer, molybdenum(VI), thermal copolymerization, solid phase extraction

\section{Introduction}

Molybdenum is a biologically important trace element, which occurs in various oxidation states in minerals rather than as free metal. Molybdenum in real water exists in the form of $\mathrm{MoO}_{4}{ }^{2-}$ ion and this form $\left(\mathrm{Mo}^{\mathrm{VI}}\right)$ is generally assumed to be the dominant oxidation state in oxic natural waters, while $\mathrm{Mo}^{\mathrm{v}}$ is thermodynamically stable in reducing waters. ${ }^{1,2}$ Molybdenum ions play an important role in enzymatic processes, and stimulate the synthesis of proteins and nucleic acids. ${ }^{3}$ Its deficiency may results in reduced growth or yield loss and even death due to accumulating nitrate, reducing amino acid concentration and falling level of vitamin metabolism in plant tissue. ${ }^{4}$ It is, however, toxic at high concentrations for both plant and human causing bone deformation and disturbances in the metabolism of fats and proteins in human. ${ }^{5}$ Molybdenum is used as a component in glass, fertilizer, catalyst, lubricant and alloy

*e-mail: majid2_haji@yahoo.com of steel. As a result, industrial effluents contain excess of molybdenum that causes detrimental effects in animals and human beings. Very low concentrations of $\mathrm{Mo}^{\mathrm{VI}}$ can be found in water supplies such as river, spring and well water. Therefore, it is important to develop a sensitive and selective method of Mo environmental monitoring to know the exposure level of this element. Mo limit in drinking water declared by environmental protection agency (EPA) is $90 \mu \mathrm{g} \mathrm{L}^{-1}$. For the determination of trace amount of Mo, a separation and a preconcentration step are usually required before its analysis. This is due to its low concentration and matrix effect in environmental samples. One of the most common methods for preconcentration and separation of analytes is solid phase extraction (SPE). Solid phase extraction is an attractive technique based on the use of a sorbent that retains the analytes. The analytes are eluted from the sorbent using a suitable solvent. SPE technique reduces solvent consumption and exposure along with, disposal cost and extraction time. Recently, imprinting polymers have been successfully utilized for 
the preconcentration and separation of trace analytes from water samples.

Molecular imprinted polymers (MIPs) have been developed over the years for carbohydrate, amino acids and their derivatives. ${ }^{6}$ Molecular imprinting is a technique for preparing polymeric materials that are capable of high molecular recognition. The resultant imprints possess a steric and chemical memory for the template. In molecular imprinting process, selected functional monomers are polymerized around a target molecule (template) in presence of a crosslinking agent..$^{7-9}$ After removal of the template trapped in a highly crosslinked polymeric matrix, selective cavities together with the shape of the template are created. ${ }^{10}$ For metal ions, molecular imprinting can be interpreted as an ionic imprinting. Ion imprinted polymers (IIPs) are similar to MIPs, but they recognize inorganic ions after imprinting. ${ }^{11-13}$ The selectivity of an ion imprinted polymer is based on the metal ion interaction with a specific ligand, coordination geometry, metal ion coordination number, charge and size. ${ }^{14-17}$

There are some reports on the nanopore IIP preparation and their applications as the solid phase extraction (SPE) sorbent for the preconcentration of the analytes present in trace amounts or their separation from other coexisting species in complex matrix. ${ }^{18-20} \mathrm{Mo}^{\mathrm{VI}}$ oxy ion imprinted particle was prepared firstly by the surface metal ion imprinting technique with a sol-gel process on the surface of amino-silica by Ren et al. ${ }^{21}$ They used $\mathrm{Mo}^{\mathrm{VI}}$ oxy ion-imprinted as an adsorbent for preconcentration and separation of $\mathrm{Mo}^{\mathrm{VI}}$ trace amounts from the water samples.

In this work nanopore molybdenum(VI)-imprinted and non-imprinted copolymers were synthesized by using methacrylic acid (MAA) as a monomer, ethylene glycoldimethacrylate (EGDMA), as crosslinking agent, and 2,2'-azobisisobutyronitrile (AIBN) as initiator, after removal of $\mathrm{Mo}^{\mathrm{VI}}$ ions, $\mathrm{Mo}^{\mathrm{VI}}$-imprinted polymer was used for solid phase extraction and preconcentration of $\mathrm{Mo}^{\mathrm{VI}}$ from aqueous solutions. The different parameters affected on the extraction of Mo ions were optimized by using one variable at a time and chemometric tools (central composite design, CCD). Finally, the analytical application and selectivity behavior of the synthesized materials were described and discussed.

\section{Experimental}

Instrumentation

A PerkinElmer (Kentucky, USA) 7300 DV Optima model inductively coupled plasma-atomic emission spectroscopy (ICP-AES) was used for the determination of metal ion. The argon gas with $99.999 \%$ (v/v) purity for ICPAES was purchased from Roham Gas Co. Measurement was made in triplicate under the operating conditions listed in Table 1.

Table 1. Optimized conditions for ICP determination of the Mo ion

\begin{tabular}{lc}
\hline \multicolumn{2}{c}{ ICP-AES ${ }^{\mathrm{a}}$ condition } \\
\hline $\mathrm{RF}^{\mathrm{b}}$ generator power / $\mathrm{kW}$ & 1.3 \\
Frequency of $\mathrm{RF}^{\mathrm{b}}$ generator / $\mathrm{MHz}$ & 40 \\
Plasma gas flow rate / $\left(\mathrm{L} \mathrm{min}^{-1}\right)$ & 15.0 \\
Auxiliary gas flow rate / $\left(\mathrm{L} \mathrm{min}^{-1}\right)$ & 1.0 \\
Nebulizer pressure flow rate / $\left(\mathrm{L} \mathrm{min}^{-1}\right)$ & 0.8 \\
Viewing high / mm & 15 \\
Sample flow rate / (mL min & $-1)$ \\
Mo wavelength / nm & 1.5 \\
\hline ICP-AES: inductively coupled plasma-atomic emission spectroscopy; \\
'RF: radiofrequency.
\end{tabular}

The infrared (IR) spectra $\left(400-4000 \mathrm{~cm}^{-1}\right)$ in $\mathrm{KBr}$ were recorded with the aid of a Vertex 70 spectrometer (Bruker, Billerica, USA). Thermogravimetric analysis was carried out using the Rheometric scientific simultaneous thermal analyzer (London, England). Nitrogen sorption studies were made by a Quantachrome NOVA instrument (Florida, USA). The morphology of the unleached and leached IIP particles were examined by scanning electron microscopy (SEM), using a Philips XL-30 scanning electron microscope. A peristaltic pump model PD-5101 (Heidolph, Germany) was used in the SPE process. A Metrohm model 744 digital pH meter (Herisau, Switzerland), equipped with a combined glass-calomel electrode was employed for the $\mathrm{pH}$ adjustments. A Hettich centrifuge model EBA 20 (Oxford, England) was employed for phase separation.

\section{Chemicals and reagents}

Ethylene glycoldimethacrylate (Merck, Darmstadt, Germany), 2,2'-azobisisobutyronitrile (98\%, m/m, Acros, USA), methacrylic acid (Sigma-Aldrich, Steinheim, Germany) and tetra- $n$-butylammonium hydroxide (20\%, $\mathrm{m} / \mathrm{m}$, Merck, Darmstadt, Germany) were applied for the synthesis of polymers with analytical reagent grades. Hydrochloric acid was obtained from Sigma-Aldrich (Steinheim, Germany). All other chemicals were of analytical reagent grades and they were purchased from Merck (Darmstadt, Germany). $\mathrm{Na}_{2} \mathrm{MoO}_{4} \cdot 2 \mathrm{H}_{2} \mathrm{O}$ (Merck, $99 \%, \mathrm{~m} / \mathrm{m}$ ) was used as the source of $\mathrm{Mo}^{\mathrm{VI}}$ and nitrate or chloride salts of other cations (all from Merck) were of the highest purity available and were used without any further purification. Stock solution of $\mathrm{Mo}^{\mathrm{VI}}\left(100 \mu \mathrm{g} \mathrm{mL}^{-1}\right)$ was prepared by dissolving appropriate amounts of 
$\mathrm{Na}_{2} \mathrm{MoO}_{4} \cdot 2 \mathrm{H}_{2} \mathrm{O}$ in deionized water in a $100 \mathrm{~mL}$ volumetric flask. Dilute solutions were prepared by appropriate dilution of the stock solution in deionized water.

Ion-imprinted polymer (IIP) preparation

The synthesis of poly(ethylene glycoldimethacrylateco-methacrylic acid) was based on the bulk polymerization method. In the first step, the inorganic complex was formed between $\mathrm{Mo}^{\mathrm{VI}}$ and thiocyanate $\left(\mathrm{SCN}^{-}\right)$in aqueous solution, thereafter the ion pair formed between the Mo-SCN inorganic complex as a bulk anion and tetrabutylammonium $\left(\mathrm{NR}_{4}^{+}\right)$as a bulk cation. For this task, the aqueous solution $1.25 \mathrm{~mol} \mathrm{~L}^{-1}$ of $\mathrm{HCl}(500 \mathrm{~mL})$, containing $5.2 \times 10^{-3} \mathrm{~mol} \mathrm{~L}^{-1}$ of $\mathrm{Mo}^{\mathrm{VI}}$ and $0.1 \mathrm{~mol} \mathrm{~L}^{-1} \mathrm{NaSCN}$ was prepared. Then, $8.2 \mathrm{~mL}$ from $\mathrm{NR}_{4} \mathrm{OH}(20 \%, \mathrm{~m} / \mathrm{m})$ was added into the Mo solution. The ion pair was formed and precipitated completely. The red precipitate was separated after 2 days, and it was dissolved in $52 \mathrm{~mL}$ acetonitrile. In order to obtain the amount of Mo in acetonitrile, the aqueous solution was analyzed before and after precipitation. The amount of Mo calculated was about $2.3 \mathrm{mmol} .20 \mathrm{~mL}$ acetonitrile solution containing $0.9 \mathrm{mmol}$ of molybdenum ion pair, $3 \mathrm{mmol}$ of MAA, $20 \mathrm{mmol}$ of EGDMA and $0.1 \mathrm{~g}$ AIBN was transferred into polymerization reactor. Following this procedure, the solution was purged thoroughly with argon gas for $2 \mathrm{~min}$ and the reaction flask was sealed immediately. The mixture was subsequently polymerized at $80{ }^{\circ} \mathrm{C}$ for 48 hours. The resulting red solid polymer was dried in an oven at $70{ }^{\circ} \mathrm{C}$ for 4 hours. The IIP was grounded in a mechanical mortar and then it was sieved $(\leq 100 \mu \mathrm{m})$. The residuary (e.g., unconverted monomer, initiator and solvent) was removed using water/methanol solution $(20 \%, \mathrm{v} / \mathrm{v})$. In order to remove the Mo ions confined in the selective cavity of the polymer, it was washed successively with $10 \%(\mathrm{v} / \mathrm{v})$ methanol in $\mathrm{HCl}\left(0.5 \mathrm{~mol} \mathrm{~L}^{-1}\right)$ and monitored simultaneously by ICP-AES. Finally, the particles were washed by distilled water and dried in an oven at $70{ }^{\circ} \mathrm{C}$ for 3 hours. To evaluate the imprinting effect of the Mo-imprinted polymer, the same procedure was adopted, in absence of Mo ion pair, which was designed as an non-imprinted polymer (NIP). The IIP and NIP polymers were further characterized by infrared spectroscopy (IR), thermal gravimetric analysis (TGA), SEM, X-ray and Brunauer-Emmett-Teller (BET) techniques.

\section{Solid-phase extraction of $\mathrm{Mo}^{\mathrm{vI}}$}

A total $200 \mathrm{mg}$ of Mo-imprinted polymer was packed into a SPE column $(6.0 \times 1.0 \mathrm{~cm}$ internal diameter $)$, made of polyethylene, a polyethylene frit was placed at both ends to prevent the loss of the polymer during the sample loading. Before loading the sample, SPE cartridge was conditioned by passing $20 \mathrm{~mL}$ deionized water at a flow rate of $1.5 \mathrm{~mL} \mathrm{~min}^{-1}$. Then, $35 \mathrm{~mL}$ of the sample containing $\mathrm{Mo}^{\mathrm{VI}}, \mathrm{SCN}^{-} \mathrm{NR}_{4}{ }^{+}$in the $\mathrm{HCl} 3 \mathrm{~mol} \mathrm{~L}^{-1}$ was passed through the column at flow rate of $1.5 \mathrm{~mL} \mathrm{~min}{ }^{-1}$ (controlled by a peristaltic pump). In this solution, number of moles of $\mathrm{SCN}^{-}$and $\mathrm{NR}_{4}{ }^{+}$were 600 and 50 moles per each mole of Mo. The column was washed with $7 \mathrm{~mL}$ distilled water at a flow rate of $1.5 \mathrm{~mL} \mathrm{~min}^{-1}$.

\section{Loading capacity}

To investigate the loading capacity of IIP, $200 \mathrm{mg}$ of IIP was packed into the SPE column and $20 \mathrm{~mL}$ of the sample containing $50 \mathrm{mg} \mathrm{L}^{-1} \mathrm{Mo}^{\mathrm{VI}}$, and equivalent of each $\mathrm{Mo}$ mole, 600 moles of $\mathrm{SCN}^{-}$and 70 moles of $\mathrm{NR}_{4}{ }^{+}$in the $\mathrm{HCl}$ $3 \mathrm{~mol} \mathrm{~L}^{-1}$ media was passed through the column at flow rate of $1.5 \mathrm{~mL} \mathrm{~min}^{-1}$. The Mo content of the sample was passed through the IIP column measured by ICP. Loading capacity of the polymer was calculated by the following equation:

$\mathrm{Q}=\frac{\left(\mathrm{C}_{\mathrm{i}}-\mathrm{C}_{\mathrm{f}}\right) \mathrm{V}}{\mathrm{W}}$

where $\mathrm{Q}$ is the loading capacity of the polymer $\left(\mathrm{mg} \mathrm{g}^{-1}\right)$; $\mathrm{C}_{\mathrm{i}}$ and $\mathrm{C}_{\mathrm{f}}$ are the concentrations of the ions in the initial solution and in the aqueous phase after passing through the IIP column, respectively $\left(\mathrm{mg} \mathrm{L}^{-1}\right) ; \mathrm{V}$ is the volume of the aqueous phase (L) and $\mathrm{W}$ is the amount of polymer $(\mathrm{g}){ }^{22}$

\section{Selectivity experiments}

In order to evaluate the selectivity of the imprinted adsorbent, $20 \mathrm{mg}$ of IIP and NIP were packed into the SPE columns. $2 \mathrm{~mL}$ of the aqueous solutions $\left(\mathrm{HCl} 3 \mathrm{~mol} \mathrm{~L}^{-1}\right)$ including $\mathrm{Mo}^{\mathrm{VI}}$ and other metallic ions $\left(\mathrm{Cu}^{2+}, \mathrm{Cr}^{3+}, \mathrm{Cd}^{2+}\right.$, $\mathrm{Pb}^{2+}, \mathrm{Zn}^{2+}, \mathrm{Mg}^{2+}, \mathrm{Co}^{2+}, \mathrm{Fe}^{3+}, \mathrm{Mn}^{2+}$ and $\left.\mathrm{U}^{6+}\right)$ binary mixtures containing $0.25 \mathrm{mg} \mathrm{L}^{-1}$ of Mo and different amount from each metallic ions with 600 moles of $\mathrm{SCN}^{-}$and 70 moles of $\mathrm{NR}_{4}^{+}$equivalent of each mole of Mo were passed through the IIP and NIP columns at the flow rate of $1.5 \mathrm{~mL} \mathrm{~min}^{-1}$. The concentration of Mo ions in the transit solution through the IIP column was measured by ICP. The parameters related to the selective performance of sorbents, such as distribution $\left(\mathrm{K}_{\mathrm{d}}\right)$ and selectivity $(\mathrm{k})$ coefficients were determined according to the literature data. ${ }^{23}$ Distribution coefficient was calculated according to:

$\mathrm{K}_{\mathrm{d}}=\left[\frac{\mathrm{C}_{\mathrm{i}}-\mathrm{C}_{\mathrm{f}}}{\mathrm{C}_{\mathrm{f}}}\right] \times \frac{\mathrm{V}_{\mathrm{s}}(\mathrm{mL})}{\text { mass of IIP }(\mathrm{g})}$ 
where $\mathrm{C}_{\mathrm{i}}, \mathrm{C}_{\mathrm{f}}$ and $\mathrm{V}_{\mathrm{s}}$ represent the initial, final solution concentrations and the volume of the solution, respectively. The selectivity coefficient is defined as the ratio between the distribution coefficient for $\mathrm{Mo}^{\mathrm{VI}}$ ions and the distribution coefficient for interfering ions as $\mathrm{k}$.

$\mathrm{k}=\frac{\mathrm{K}_{\mathrm{d}}^{\mathrm{Mo}}}{\mathrm{K}_{\mathrm{d}}^{\mathrm{M}^{\mathrm{n}}}}$

\section{Results and Discussion}

\section{Characterization studies}

The $\mathrm{Mo}^{\mathrm{VI}}$-IIP particles were characterized by different characterization techniques. The IR spectra of the NIP, unleached IIP and leached IIP particles were recorded by the $\mathrm{KBr}$ pellet method using a vertex spectrometer. The absence of bands in the region of $1638-1648 \mathrm{~cm}^{-1}$ indicates the absence of vinyl groups in the polymer particles. This observation could be possibly attributed to the polymerization of both MAA and EGDMA (Figure 1). The three peaks at 1108, 2042 and $2354 \mathrm{~cm}^{-1}$, just in the spectra of unleached polymer (UIIP), could be attributed to $v_{\mathrm{C}-\mathrm{N}}$ (in tetrabuthylamonium), $v_{\mathrm{SCN}}$ and $\mathrm{v}_{\mathrm{C}=\mathrm{N}}$ (in $\mathrm{SCN}$ ) respectively, illustrating that the ion pair was removed completely during the leaching process (LIIP). The IR spectra of NIP and leached IIP were found to be almost similar indicating that all the polymer particles have similar backbones. The $\mathrm{C}=\mathrm{O}$ stretching vibration at $1728 \mathrm{~cm}^{-1}$ in the NIP was shifted to $1722 \mathrm{~cm}^{-1}$ in the UIIP and to 1730 in the LIIP material, showing that the oxygen of $\mathrm{C}=\mathrm{O}$ group is involved in the Mo interaction.

Figure 2 shows the thermal degradation behaviors of unleached IIP, leached IIP and NIP particles. Unleached IIP presented four main weight loss steps in the ranges:

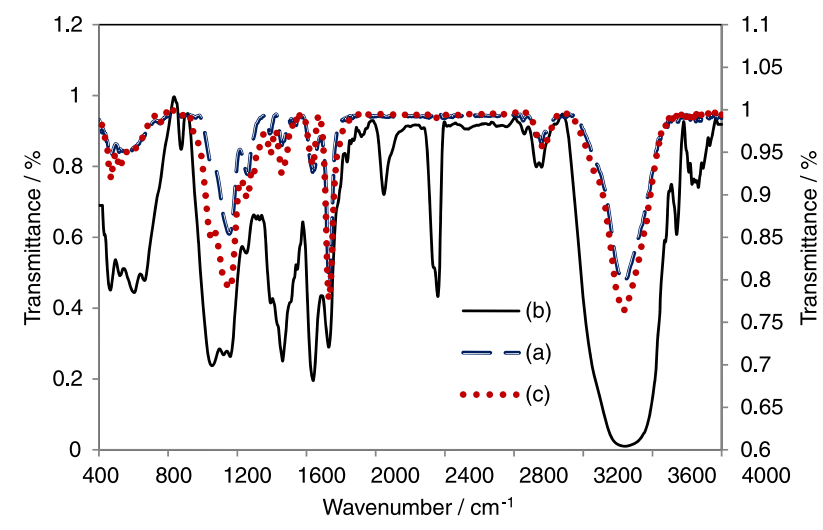

Figure 1. IR spectra of the (a) NIP; (b) unleached IIP; (c) leached IIP particles.

$131-231{ }^{\circ} \mathrm{C}, 231-350{ }^{\circ} \mathrm{C}, 350-414{ }^{\circ} \mathrm{C}$ and $450-532{ }^{\circ} \mathrm{C}$. Leached IIP presented three main weight loss steps in the ranges: $150-236{ }^{\circ} \mathrm{C}, 255-393{ }^{\circ} \mathrm{C}$ and $393-550{ }^{\circ} \mathrm{C}$, also NIP presented two main weight loss steps in the ranges $255-393{ }^{\circ} \mathrm{C}$ and $432-532{ }^{\circ} \mathrm{C}$. The first step for unleached IIP in the range of $131-231^{\circ} \mathrm{C}$ and for leached IIP in the range of $150-236^{\circ} \mathrm{C}$ are due to the presence of physisorbed water. In the second step, two pronounced weight losses were observed in unleached IIP within the ranges of $231-350{ }^{\circ} \mathrm{C}$ and $450-532{ }^{\circ} \mathrm{C}$ with maximum degradation temperatures $\left(\mathrm{T}_{\text {max }}\right)$ of 341 and $490^{\circ} \mathrm{C}$ respectively, in leached IIP within the ranges of $255-393{ }^{\circ} \mathrm{C}$ and $393-550^{\circ} \mathrm{C}$ with $\mathrm{T}_{\max }$ of 352 and $518{ }^{\circ} \mathrm{C}$ and in NIP within the ranges of $255-393{ }^{\circ} \mathrm{C}$ and $432-532{ }^{\circ} \mathrm{C}$ with $\mathrm{T}_{\max }$ of 332 and $507{ }^{\circ} \mathrm{C}$ which was attributed to the decomposition of poly(EGDMA) segment. The third step, for unleached IIP with $\mathrm{T}_{\max } 386^{\circ} \mathrm{C}$ corresponds to the decomposition of the ion pair. For NIP, the end product has higher residual yield $(12.5 \%)$ when compared with the unleached IIP (5.8\%) and leached IIP $(0.625 \%)$. This difference could be related to the absence of coordination between EGDMA and MAA with the ion pair
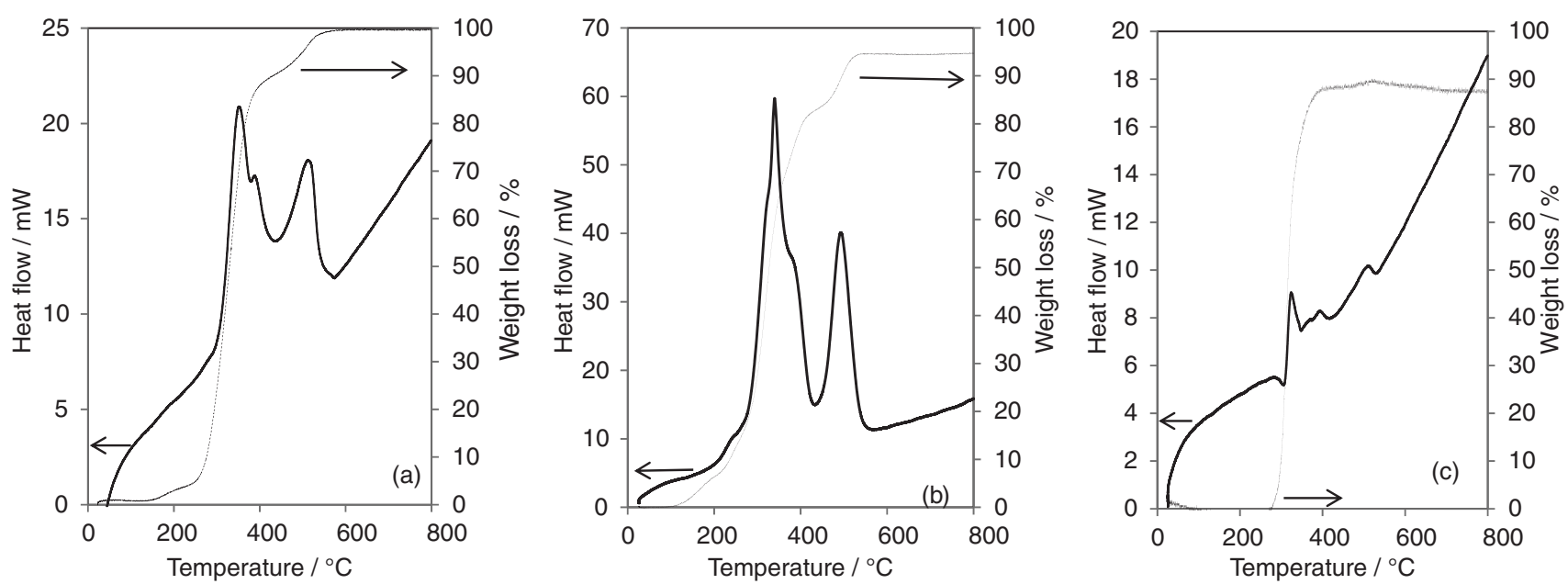

Figure 2. TG and DTG curve for (a) leached IIP; (b) unleached IIP; (c) NIP particles. 
Table 2. Nitrogen sorption data for leached IIP, unleached IIP and NIP particle

\begin{tabular}{lccc}
\hline & BET $^{\mathrm{a}}$ surface area $/\left(\mathrm{m}^{2} \mathrm{~g}^{-1}\right)$ & Pore volume $/\left(\mathrm{cm}^{3} \mathrm{~g}^{-1}\right)$ & Pore diameter $^{\mathrm{c}} / \mathrm{nm}^{\mathrm{b}}$ \\
\hline IIP-leached $^{\mathrm{d}}$ & $160.8\left(48.94^{\mathrm{e}}, 23.0^{\mathrm{f}}\right)$ & $0.26\left(0.1349^{\mathrm{e}}, 0.59^{\mathrm{f}}\right)$ & $1.83\left(11.02^{\mathrm{e}}, 1.5-10^{\mathrm{f}}\right)$ \\
NIPg $^{\mathrm{g}}$ & $72.1\left(51.64^{\mathrm{e}}\right)$ & $0.07\left(0.1359^{\mathrm{e}}\right)$ & $1.436\left(10.53^{\mathrm{e}}\right)$ \\
Unleached-IIP & 29.4 & 0.04 & 1.434 \\
\hline
\end{tabular}

aBET: Brunauer-Emmett-Teller; bby method BET; 'by method BJH-Barrett-Joyner-Halenda; dIP: ion imprinted polymer; ${ }^{\mathrm{e}}$ reference 21; ${ }^{\mathrm{f}}$ reference 24; ${ }^{g}$ NIP: non-imprinted polymer.

during synthesis, which can lead to additional interactions between the monomers, resulting in higher residual yield (12.5\%) for NIP.

The synthesized IIP particles were characterized using nitrogen sorption studies, in order to know the surface properties of the leached IIP, unleached IIP and NIP particles. The surface area was determined by applying the BET equation. The data are recorded in Table 2 for the leached, unleached and non-imprinted polymer particles. It is clearly seen that porosity changes after the removal of molybdenum ions from the IIP particles. A comparison between the surface properties of synthesized IIP and other SPE materials for the extraction and determination of Mo is presented in Table 2.

The morphology of the polymers was assessed by SEM. The respective micrographs shown in Figures $3 a$ and $3 b$, illustrate that the porosity is changed after the removal of the molybdenum ions. In addition, it is clear that the pore size in the leached polymers was in the nano-range, corresponding to the ion size.

The energy dispersive X-ray (EDX) spectra for the unleached and leached polymer particles confirmed that the absence of molybdenum in EDX spectrum of the leached polymer particles illustrates the complete removal of molybdenum from the polymer matrix in leaching step.

Optimization of sorption and elution of $\mathrm{Mo}^{\mathrm{VI}}$ ions from the IIP particles in the column

The critical variables (e.g., concentrations of $\mathrm{HCl}, \mathrm{NR}_{4}{ }^{+}$, and $\mathrm{SCN}^{-}$in the sample and elution condition) affected the extraction of molybdenum ions from water samples and their variation ranges were first selected based on a preliminary one variable at a time (OVAT) procedure, and further optimization was then performed by response surface methodology (RSM), based on rotatable face central composite design (FCCD).

According to the results obtained by OVAT method, there are several factors such as complex formation time, $\mathrm{HCl}, \mathrm{SCN}^{-}$and $\mathrm{NR}_{4}{ }^{+}$concentration in the sample, which may affect the extraction process. To find the optimum condition on the extraction of molybdenum ions from
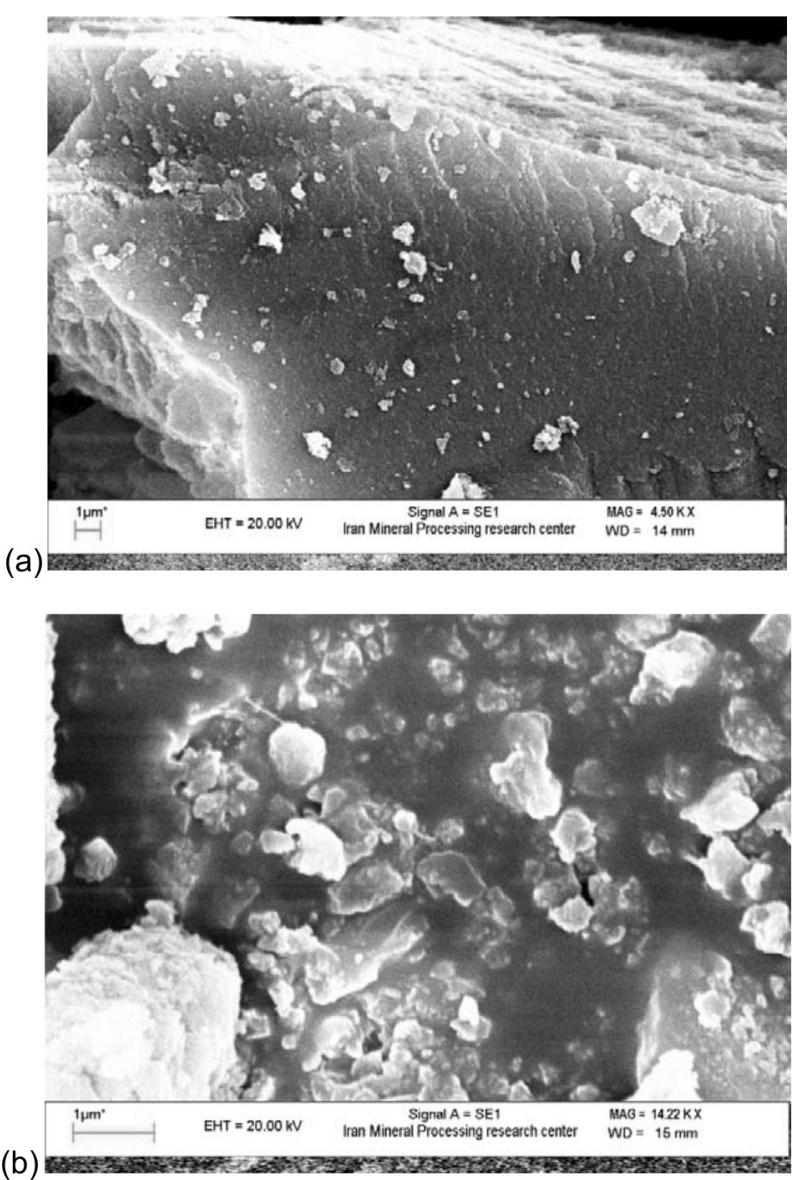

Figure 3. SEM images of the (a) unleached; (b) leached IIP particles.

water samples, and to investigate the probable interaction between variables, RSM based on rotatable FCCD was used.

\section{Preliminary OVAT procedure}

Various experimental parameters such as concentrations of $\mathrm{HCl}, \mathrm{NR}_{4}{ }^{+}, \mathrm{SCN}^{-}$in the sample and elution condition which may effect on the extraction of $\mathrm{Mo}^{\mathrm{VI}}$ ions were investigated. $200 \mathrm{mg}$ IIP was packed in the column. The created conditions were chosen by preliminary tests as follows: $20 \mathrm{~mL}$ solution containing $1 \mathrm{mg} \mathrm{L}^{-1} \mathrm{Mo}^{\mathrm{VI}}$, and equivalent of each Mo mol, 400 moles of $\mathrm{SCN}^{-}$and 50 moles of $\mathrm{NR}_{4}{ }^{+}$was prepared. The flow rate of the sample solution through the column was chosen $0.74 \mathrm{~mL} \mathrm{~min}^{-1}$. In 
order to elute $\mathrm{Mo}^{\mathrm{VI}}$ from IIP, $10 \mathrm{~mL} \mathrm{HCl} 0.5 \mathrm{~mol} \mathrm{~L}^{-1}$ was passed through the column at flow rate of $0.26 \mathrm{~mL} \mathrm{~min}^{-1}$.

\section{$\mathrm{HCl}$ concentration effect}

The effect of $\mathrm{HCl}$ concentration was investigated in the range of $0.15-2 \mathrm{~mol} \mathrm{~L}^{-1}$ (Figure 4). The maximum percentage of recovery of Mo ions was determined at $\mathrm{HCl}$ $2 \mathrm{~mol} \mathrm{~L}^{-1}$.

\section{$\mathrm{NR}_{4}{ }^{+}$concentration effect}

In these series of experiments, the concentrations of all reagents and conditions were kept constant while the concentration of $\mathrm{NR}_{4}^{+}$was varied between 0 to 50 moles of $\mathrm{NR}_{4}{ }^{+}$equivalent of each mole of Mo. Based on the results, 50 moles of $\mathrm{NR}_{4}{ }^{+}$equivalent of Mo mole have the maximum recovery of $\mathrm{Mo}^{\mathrm{VI}}$ from sample waters.

\section{$\mathrm{SCN}^{-}$concentration effect}

The effect of $\mathrm{SCN}^{-}$concentration on the extraction was also examined (Figure 4). In this series of experiments, only the $\mathrm{SCN}^{-}$concentration varied in the range 10-500 moles of $\mathrm{SCN}^{-}$equivalent of Mo mole. The recovery percentage of $\mathrm{Mo}^{\mathrm{VI}}$ was significantly affected by the concentration of $\mathrm{SCN}^{-}$.

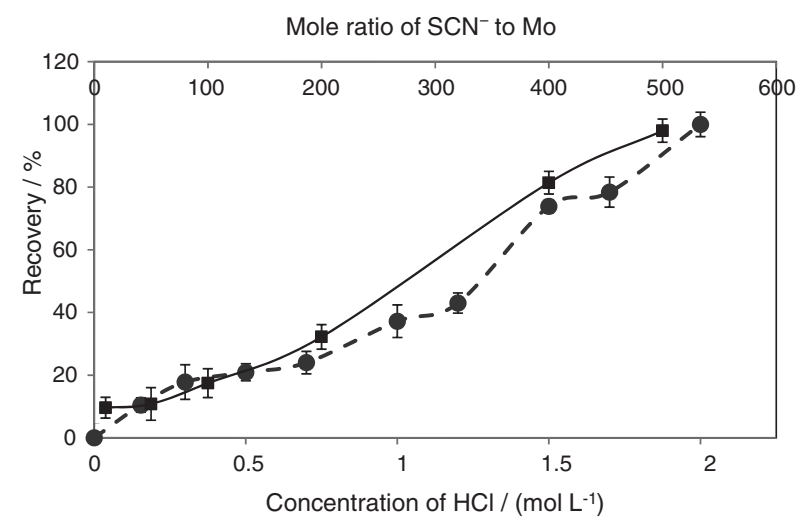

Figure 4. Effect of concentration of $\mathrm{HCl}(\bullet)$ experimental conditions: sample; $20 \mathrm{~mL}$ containing concentration of Mo: $1 \mathrm{mg} \mathrm{mL}^{-1}$; mole of $\mathrm{SCN}^{-}$per mole of Mo: 400; mole of $\mathrm{NR}_{4}^{+}$per mole of Mo: 50; eluent: $10 \mathrm{~mL} \mathrm{HCl} 0.5 \mathrm{~mol} \mathrm{~L}^{-1}$; sample flow rate: $0.74 \mathrm{~mL} \mathrm{~min}^{-1}$; eluent flow rate: $0.26 \mathrm{~mL} \mathrm{~min}^{-1}$. Concentration of $\mathrm{SCN}^{-}(\mathbf{\square})$ experimental conditions: sample; $20 \mathrm{~mL}$ containing concentration of Mo: $1 \mathrm{mg} \mathrm{mL}^{-1}$ in $\mathrm{HCl}$ $2 \mathrm{~mol} \mathrm{~L}^{-1}$ other conditions are similar on the adsorption of $\mathrm{Mo}^{\mathrm{VI}}$ on the $\mathrm{Mo}^{\mathrm{VI}}$-imprinted polymer.

\section{Effect of flow rate}

The effect of sample and eluent solution flow rate through the column on the retention and recovery of Mo ions was investigated in the range of 0.25 to $1.5 \mathrm{~mL} \mathrm{~min}^{-1}$. It was found that the adsorption and elution of the metal ions were reproducible in the flow rate range of 0.25 to $1.5 \mathrm{~mL} \mathrm{~min}^{-1}$. Thus, the flow rates of the sample and eluent solution were adjusted $1.5 \mathrm{~mL} \mathrm{~min}^{-1}$ throughout the further studies.

\section{Choice of eluent}

In order to choose the most effective eluent for quantitative stripping of the retained Mo ions from the column, different eluents such as, $\mathrm{HCl}\left(0.5 \mathrm{~mol} \mathrm{~L}^{-1}\right), \mathrm{HCl}$ $\left(0.1 \mathrm{~mol} \mathrm{~L}^{-1}\right), \mathrm{NaOH}\left(0.1 \mathrm{~mol} \mathrm{~L}^{-1}\right)$ and water was chosen. According to the results, distilled water turned out to be the most effective eluent for quantitative elution. The decrease in elution of Mo at acidic media $(\mathrm{pH}<7)$ is due to the existence of molybdenum in the form of $\mathrm{Mo}^{6+}$. This form of ion is suitable for interaction with SPE pore. At higher $\mathrm{pH}$, molybdenum is converted to $\mathrm{MoO}_{4}{ }^{2-}$, so elution was well done. In order to find optimum volume of the elution solvent, different volumes of distilled water from 1 to $10 \mathrm{~mL}$ were used; the results are displayed in Figure 5 . As seen, quantitative elution was attained using volumes more than $6 \mathrm{~mL}$.

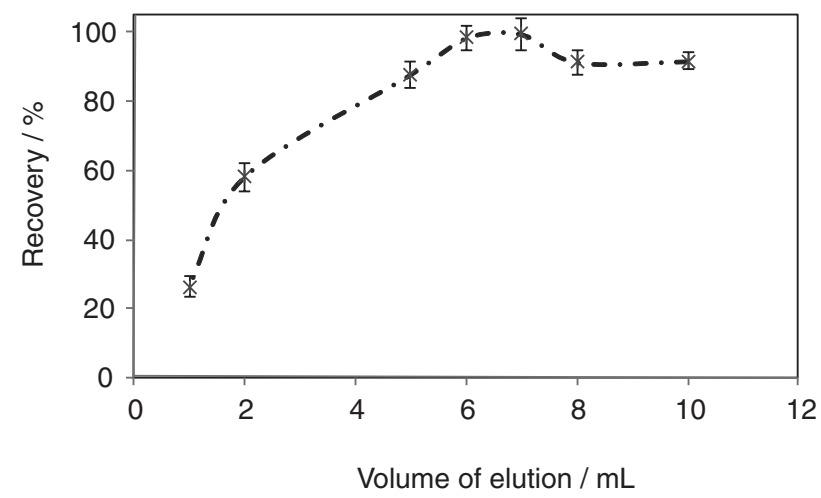

Figure 5. The effect of volume eluent on elution of Mo adsorbed on IIP (experimental conditions: sample; $20 \mathrm{~mL}$ containing concentration of Mo: $1 \mathrm{mg} \mathrm{mL}^{-1}$; mole of $\mathrm{SCN}^{-}$per mole of Mo: 500; mole of $\mathrm{NR}_{4}{ }^{+}$per mole of Mo: 50 in $\mathrm{HCl} 2 \mathrm{~mol} \mathrm{~L}^{-1}$; eluent: $10 \mathrm{~mL}$ water; sample flow rate: $1.4 \mathrm{~mL} \mathrm{~min}^{-1}$; eluent flow rate: $1.4 \mathrm{~mL} \mathrm{~min}^{-1}$ ).

\section{Response surface methodology}

In order to obtain a high recovery and enrichment factor, the effect of different parameters such as time of complex formation, concentration of $\mathrm{HCl}$, amount of $\mathrm{SCN}^{-}$and $\mathrm{NR}_{4}{ }^{+}$in the sample, were analyzed. Response surface methodology including face-center central composite approach was utilized to find the optimum values of effective variables involved in the system.

The design was built up of four factors at three levels (Table 3$)$ with 16 axial points $(\alpha=1)$. In order to estimate the experimental error, eight replicas at the central point were applied. The design was rotatable, this means that the design had equidistant points from the center. This procedure led to 32 experiments (Table 4), where the experimental 
results were analyzed by a regression procedure based on the RSM. ${ }^{25}$ Composite design is well known as a useful method to describe the curvature dependency of a typical response to its variables, which needed to explain a nonlinear variation behavior. The model that can be fitted to a composite design is an empirical function, determined by the statistical correlation suitability of the observed responses and experimental factors. For this purpose, a second-order four variable-polynomial model equation is usually used (equation 4). ${ }^{26}$

Table 3. The experimental variables and levels of the FCCD (face central composite design)

\begin{tabular}{lccc}
\hline \multirow{2}{*}{ Factor } & \multicolumn{3}{c}{ Level } \\
\cline { 2 - 4 } & Low & Center & High \\
\hline A: time / min & 0.0 & 30.0 & 60.0 \\
$\mathrm{~B}: \mathrm{HCl} /\left(\mathrm{mol} \mathrm{L}^{-1}\right)$ & 0.3 & 1.65 & 3.0 \\
$\mathrm{C}: \mathrm{NR}_{4}^{+}$(mol ratio) & 0.0 & 35.0 & 70.0 \\
D: $\mathrm{SCN}^{-}$(mol ratio) & 50.0 & 325.0 & 600.0 \\
\hline
\end{tabular}

$\mathrm{Y}=\mathrm{a}_{0}+\mathrm{a}_{1} \mathrm{x}_{1}+\mathrm{a}_{2} \mathrm{x}_{2}+\mathrm{a}_{3} \mathrm{x}_{3}+\mathrm{a}_{4} \mathrm{x}_{4}+\mathrm{a}_{11} \mathrm{x}_{1}^{2}+\mathrm{a}_{22} \mathrm{x}^{2}+$

$a_{33} x_{3}^{2}+a_{44} x_{4}^{2}+a_{12} x_{1} x_{2}+a_{13} x_{1} x_{3}+a_{14} x_{1} x_{4}+a_{23} x_{2} x_{3}+$

$\mathrm{a}_{24} \mathrm{x}_{2} \mathrm{x}_{4}+\mathrm{a}_{34} \mathrm{x}_{3} \mathrm{x}_{4}$

where $\mathrm{Y}$ is the predicted response. The response here is the percentage of molybdenum ion extraction (Table 3 ). $\mathrm{x}_{1}, \mathrm{x}_{2}$, $\mathrm{x}_{3}$ and $\mathrm{x}_{4}$ are the independent variables or the experimental factors. The linear coefficients $a_{1}-a_{4}$ express the linear effect of each variable; $a_{11}, a_{22}, a_{33}$ and $a_{44}$ coefficients express the quadratic effects; $a_{12}-a_{14}, a_{23}-a_{24}$ and $a_{34}$, coefficients express interactive effects between the variables and $\mathrm{a}_{0}$ is a constant corresponding to the central point of experimental variables. The statistical design, data analysis and various plots were obtained by using Minitab statistical software.

The coefficients of the empirical model equation 1 and their statistical characteristics were evaluated (Table 5).

The estimated value of the determination coefficient $\left(\mathrm{R}^{2}\right)$, expressed as a percentage, indicates that the model fits $97.6 \%$ of the experimental raw data. The quality of the regression, estimated by the analysis of variance (ANOVA), is shown in Table 6. If the model were a strong predictor of the experimental data, the computed F-value would be higher than the tabular F-value. Generally, the $p$-levels can be used as a tool to check the significance of each of the regression coefficients. This information is necessary to explain the correlation of the mutual interaction between the factors. The smaller the magnitude of the $p$, the more significant is the corresponding coefficient. The $p$-values in Table 6 reveal that one of the interaction terms in model (equation 4) at the $95 \%$ confidence level is significant
Table 4. Design table showing the randomized run order of the experiment, and the uncoded values of the different variables in the experimental design for the determination of the modeled response (equation 4)

\begin{tabular}{|c|c|c|c|c|c|}
\hline Number & time / min & $\begin{array}{c}\mathrm{HCl} / \\
\left(\mathrm{mol} \mathrm{L}^{-1}\right)\end{array}$ & $\begin{array}{c}\mathrm{NR}_{4}^{+} \\
\text {(mol ratio) }\end{array}$ & $\begin{array}{c}\mathrm{SCN}^{-} \\
\text {(mol ratio) }\end{array}$ & Response \\
\hline 1 & 30 & 1.65 & 35 & 325 & 46.8 \\
\hline 2 & 0 & 0.3 & 0 & 50 & 14.0 \\
\hline 3 & 60 & 3 & 0 & 50 & 42.8 \\
\hline 4 & 30 & 1.65 & 35 & 325 & 40.4 \\
\hline 5 & 30 & 3 & 35 & 325 & 67.6 \\
\hline 6 & 0 & 0.3 & 70 & 50 & 5.9 \\
\hline 7 & 0 & 0.3 & 0 & 600 & 11.8 \\
\hline 8 & 0 & 3 & 0 & 600 & 89.4 \\
\hline 9 & 60 & 0.3 & 0 & 50 & 9.8 \\
\hline 10 & 60 & 0.3 & 70 & 50 & 3.8 \\
\hline 11 & 30 & 1.65 & 35 & 325 & 42.2 \\
\hline 12 & 30 & 1.65 & 35 & 325 & 39.8 \\
\hline 13 & 30 & 1.65 & 35 & 325 & 39.2 \\
\hline 14 & 0 & 3 & 0 & 50 & 24.4 \\
\hline 15 & 60 & 3 & 70 & 50 & 28.7 \\
\hline 16 & 0 & 3 & 70 & 50 & 34.5 \\
\hline 17 & 60 & 3 & 70 & 600 & 100.0 \\
\hline 18 & 30 & 1.65 & 35 & 325 & 42.3 \\
\hline 19 & 30 & 1.65 & 35 & 600 & 67.4 \\
\hline 20 & 60 & 1.65 & 35 & 325 & 44.3 \\
\hline 21 & 30 & 1.65 & 0 & 325 & 31.1 \\
\hline 22 & 30 & 1.65 & 35 & 325 & 43.9 \\
\hline 23 & 30 & 1.65 & 35 & 50 & 8.1 \\
\hline 24 & 30 & 0.3 & 35 & 325 & 8.2 \\
\hline 25 & 60 & 3 & 0 & 600 & 100.0 \\
\hline 26 & 60 & 0.3 & 0 & 600 & 8.4 \\
\hline 27 & 30 & 1.65 & 70 & 325 & 43.1 \\
\hline 28 & 60 & 0.3 & 70 & 600 & 17.4 \\
\hline 29 & 30 & 1.65 & 35 & 325 & 35.5 \\
\hline 30 & 0 & 0.3 & 70 & 600 & 17.2 \\
\hline 31 & 0 & 3 & 70 & 600 & 100.0 \\
\hline 32 & 0 & 1.65 & 35 & 325 & 36.9 \\
\hline
\end{tabular}

$(p<0.05)$, while all of the linear, square terms and the remaining of the interaction terms are not significant $(p>0.05)$. This matter is a confirmation being necessity for a significant correction regarding the number of terms in the model equation 1 and must be regards as ignored terms.

Table 6 also shows that, in the model obtained with total terms, "lack of fit F-value" $(=0.031)$ is also significant with correction regarding the number of terms in model equation 4 , when eliminated from time, $\mathrm{NR}_{4}{ }^{+}$and square term, as well as the obtained ANOVA table (Table 7) show an improvement in "lack of fit F-value" (= 0.063).

A point of maximum response could visually be determined from Figure 6 . As demonstrated, the maximum point on the response surfaces has been located in the following values of variables: concentration of 
Table 5. Estimated regression coefficients for the quadratic response (equation 4)

\begin{tabular}{lccc}
\hline Term & Coefficient & SE coefficient ${ }^{\mathrm{a}}$ & $p^{\mathrm{b}}$ \\
\hline Constant & 4.8037 & 5.96111 & 0.431 \\
time $/ \mathrm{min}$ & -0.0963 & 0.26582 & 0.722 \\
$\mathrm{HCl} /\left(\mathrm{mol} \mathrm{L}^{-1}\right)$ & 7.3069 & 6.98126 & 0.310 \\
$\mathrm{NR}_{4}^{+}(\mathrm{mol} \mathrm{ratio})$ & 0.0822 & 0.22784 & 0.723 \\
$\mathrm{SCN}^{-}(\mathrm{mol}$ ratio $)$ & 0.0030 & 0.03330 & 0.929 \\
time $\times$ time & 0.0018 & 0.00405 & 0.654 \\
$\mathrm{HCl} \times \mathrm{HCl}^{+}$ & -0.5746 & 2.00213 & 0.778 \\
$\mathrm{NR}_{4}{ }^{+} \times \mathrm{NR}_{4}^{+}$ & -0.0015 & 0.00298 & 0.623 \\
$\mathrm{SCN}^{-} \times \mathrm{SCN}^{-}$ & -0.0000 & 0.00005 & 0.745 \\
time $\times \mathrm{HCl}^{-}$ & 0.0504 & 0.03631 & 0.183 \\
time $\times \mathrm{NR}_{4}^{+}$ & -0.0017 & 0.00140 & 0.233 \\
time $\times \mathrm{SCN}^{-}$ & 0.0000 & 0.00018 & 0.967 \\
$\mathrm{HCl}^{+} \times \mathrm{NR}_{4}^{+}$ & 0.0082 & 0.03112 & 0.796 \\
$\mathrm{HCl}^{+} \times \mathrm{SCN}^{-}$ & 0.0400 & 0.00396 & 0.000 \\
$\mathrm{NR}_{4}{ }^{+} \times \mathrm{SCN}^{-}$ & 0.0003 & 0.00015 & 0.085 \\
$\mathrm{~S}^{\mathrm{c}}=5.882$ & $\mathrm{R}-\mathrm{sq}{ }^{\mathrm{d}}=97.6 \%$ & $\mathrm{R}-\mathrm{sq}(\mathrm{adj})^{\mathrm{e}}=95.6 \%$ & \\
\hline
\end{tabular}

aSE coefficient: standard error of coefficient; ${ }^{\mathrm{b}} p$ : statistical parameter; ${ }^{\mathrm{C}} \mathrm{S}$ : standard deviation; ${ }^{\mathrm{d}} \mathrm{R}$-sq: regression-squared; ${ }^{\mathrm{e}} \mathrm{R}-\mathrm{sq}(\mathrm{adj})$ : regressionsquared adjusted.
$\mathrm{HCl}=3 \mathrm{~mol} \mathrm{~L}^{-1}$ and 600 moles of $\mathrm{SCN}^{-}$equivalent of each Mo mole. According to the results of OVAT tests, 70 moles of $\mathrm{NR}_{4}{ }^{+}$equivalent of each Mo mole is needed to ensure complete extraction of $\mathrm{Mo}^{\mathrm{VI}}$.

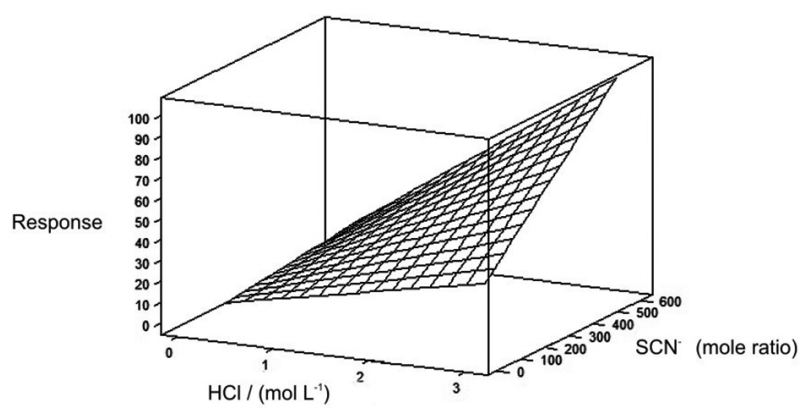

Figure 6. Three-dimensional response surface plots.

\section{Test of optimized extraction}

The SPE columns were packed with $20 \mathrm{mg}$ of IIP and NIP. $20 \mathrm{~mL} \mathrm{HCl}$ solution $\left(3 \mathrm{~mol} \mathrm{~L}^{-1}\right)$ containing $\mathrm{Mo}^{\mathrm{VI}}$ $\left(0.25 \mathrm{mg} \mathrm{L}^{-1}\right), 600$ moles of $\mathrm{SCN}^{-}$and 70 moles of $\mathrm{NR}_{4}^{+}$ equivalent of each Mo mole was prepared and passed through the columns. The molybdenum ions were eluted from the IIP particles by using $10 \mathrm{~mL}$ distilled water. The

Table 6. Analysis of variance for the quadratic response (equation 4)

\begin{tabular}{|c|c|c|c|c|c|c|}
\hline Source & $\mathrm{DF}^{\mathrm{a}}$ & Seq. SS ${ }^{b}$ & Adj. SS ${ }^{c}$ & Adj. $\mathrm{MS}^{\mathrm{d}}$ & $\mathrm{F}^{\mathrm{e}}$ & $p^{\mathrm{f}}$ \\
\hline Regression & 14 & 23673.1 & 23673.14 & 160.94 & 48.87 & 0.000 \\
\hline Linear & 4 & 19854.9 & 63.74 & 15.94 & 0.46 & 0.764 \\
\hline Square & 4 & 51.7 & 51.69 & 12.92 & 0.37 & 0.824 \\
\hline Interaction & 6 & 3766.5 & 3766.53 & 627.76 & 18.14 & 0.000 \\
\hline Residual error & 17 & 588.2 & 588.21 & 34.60 & & \\
\hline Lack-of-fit & 10 & 507.3 & 507.34 & 50.73 & 4.39 & 0.031 \\
\hline Pure error & 7 & 80.9 & 80.87 & 11.55 & & \\
\hline Total & 31 & 25261.4 & & & & \\
\hline
\end{tabular}

${ }^{a}$ DF: Degrees of freedom; 'beq. SS: sequential sum of squares; ${ }^{\mathrm{c} A d j . ~ S S: ~ a d j u s t e d ~ s u m ~ o f ~ s q u a r e s ; ~}{ }^{\mathrm{d} A d j}$. MS: adjusted mean squares = Adj. SS / DF; ${ }^{\mathrm{e}} \mathrm{F}$ : F-value is calculated with: Adj. MS for any parameter to Adj. MS of residual error; ${ }^{\mathrm{f}}$ : : statistical parameter.

Table 7. Analysis of variance for the quadratic response (equation 4)

\begin{tabular}{|c|c|c|c|c|c|c|}
\hline Source & $\mathrm{DF}^{\mathrm{a}}$ & Seq. $\mathrm{SS}^{\mathrm{b}}$ & Adj. SS ${ }^{c}$ & Adj. $\mathrm{MS}^{\mathrm{d}}$ & $\mathrm{F}^{\mathrm{e}}$ & $p^{\mathrm{f}}$ \\
\hline Regression & 3 & 23338.2 & 23338.2 & 7779.41 & 235.96 & 0.000 \\
\hline Linear & 2 & 19809.6 & 983.8 & 491.90 & 14.92 & 0.000 \\
\hline Interaction & 1 & 3528.7 & 3528.7 & 3528.66 & 107.03 & 0.000 \\
\hline Residual error & 28 & 923.1 & 923.1 & 32.97 & & \\
\hline Lack-of-fit & 5 & 321.8 & 321.8 & 64.36 & 2.46 & 0.063 \\
\hline Pure error & 23 & 601.3 & 601.3 & 26.14 & & \\
\hline Total & 31 & 24261.4 & & & & \\
\hline
\end{tabular}

${ }^{\mathrm{a} D F}$ : Degrees of freedom; 'beq. SS: sequential sum of squares; ${ }^{\mathrm{c} A d j . ~ S S: ~ a d j u s t e d ~ s u m ~ o f ~ s q u a r e s ; ~}{ }^{\mathrm{d} A d j}$. MS: adjusted mean squares = Adj. SS / DF; ${ }^{\mathrm{e}} \mathrm{F}$ : F-value is calculated with: Adj. MS for any parameter to Adj. MS of residual error; ${ }^{\mathrm{f}} p$ : statistical parameter. 
solution and eluent were passed through the column at flow rate of $1.5 \mathrm{~mL} \mathrm{~min}^{-1}$. Their content in the eluent were determined by ICP (Table 8 ).

Table 8. Distributions coefficients of IIP and NIP for $\mathrm{Mo}^{\mathrm{VI}}$ ions under optimum conditions

\begin{tabular}{|c|c|}
\hline \multirow{2}{*}{ Sorbent } & $\mathrm{K}_{\mathrm{d}} /\left(\mathrm{mL} \mathrm{g}^{-1}\right)$ \\
\hline & $\mathrm{Mo}^{\mathrm{VI}}$ \\
\hline IIP & 48.90 \\
\hline NIP & 2.32 \\
\hline
\end{tabular}

Loading capacity

The loading capacity is an important factor to evaluate the IIPs. In order to investigate the adsorption capacity of molybdenum on the imprinted polymer particles, $200 \mathrm{mg}$ of polymer particles was packed in a column and a solution of molybdenum under the optimum conditions was passed through the column. The adsorption capacity of the imprinted sorbent calculated was $3.77 \mathrm{mg} \mathrm{g}^{-1}$.

\section{Selectivity studies}

The selectivity coefficient $(\mathrm{k})$ is an indicator to express an adsorption affinity of recognition sites for $\mathrm{Mo}^{\mathrm{VI}}$. Competitive adsorptions of $\mathrm{Mo} / \mathrm{metal}$ foreign ions in binary mixture solutions were also investigated in column studies. Table 9 summarizes $\mathrm{K}_{\mathrm{d}}$ and $\mathrm{k}$ values for metal ions of interest with respect to $\mathrm{Mo}^{\mathrm{VI}}$. All of the cations examined did not interfere with the extraction of $\mathrm{Mo}^{\mathrm{VI}}$. Since the chloride and nitrate salts employed in this study were without any interference. One important result is that Mo is separated from uranium with the IIP. This feature can be used for Mo remove from uranium in the production process of nuclear fuel.

\section{Breakthrough volume study}

As may be known, breakthrough volume is sample volume that adsorption of analyte is completely performed. To find out breakthrough volume, different volumes $(20,35,40,50,100,200,250$ and $350 \mathrm{~mL})$ of solution $\mathrm{HCl} 3 \mathrm{~mol} \mathrm{~L}^{-1}$ containing $20 \mu \mathrm{g} \mathrm{Mo} \mathrm{VI}^{\mathrm{VI}}$ and 600 moles of $\mathrm{SCN}$ and 70 moles of $\mathrm{NR}_{4}^{+}$equivalent of each mole of Mo were passed through the IIP $(200 \mathrm{mg})$ column at the flow rate $1.5 \mathrm{~mL} \mathrm{~min}^{-1}$. Elution of the SPE column was performed with $10 \mathrm{~mL}$ of distilled water at the flow rate $1.5 \mathrm{~mL} \mathrm{~min}^{-1}$. As shown in Figure 7, the recovery value of molybdenum(VI) was quantitative (>95\%) in the sample volume range of $20-35 \mathrm{~mL}$.

Table 9. Selectivity parameters $\left(\mathrm{K}_{\mathrm{d}}\right.$ and $\mathrm{k}$ ) and recovery of $0.25 \mathrm{mg} \mathrm{L}^{-1} \mathrm{Mo}^{\mathrm{VI}}$ from aqueous binary mixture of Mo/metal ions solution by the IIP polymer

\begin{tabular}{|c|c|c|c|c|}
\hline $\begin{array}{l}\text { Binary mixture of } \mathrm{Mo} / \text { metal } \\
\text { foreign ions }\end{array}$ & Concentration of ions / $\left(\mathrm{mg} \mathrm{L}^{-1}\right)$ & Recovery of ion / \% & $\mathrm{K}_{\mathrm{d}}{ }^{\mathrm{a}} /\left(\mathrm{mL} \mathrm{g}^{-1}\right)$ & $\mathrm{k}^{\mathrm{b}}$ \\
\hline $\mathrm{Cr}^{\mathrm{III}}$ & 0.25 & 5.6 & 5.93 & \multirow{2}{*}{22} \\
\hline $\mathrm{Mo}^{\mathrm{VI}}$ & 0.25 & 56.6 & 130.43 & \\
\hline $\mathrm{Pb}^{\Pi I}$ & 0.25 & 5.4 & 5.70 & \multirow[b]{2}{*}{16} \\
\hline $\mathrm{Mo}^{\mathrm{VI}}$ & 0.25 & 47.4 & 90.26 & \\
\hline $\mathrm{Cd}^{\mathrm{II}}$ & 0.25 & 12.5 & 14.28 & \multirow{2}{*}{12} \\
\hline $\mathrm{Mo}^{\mathrm{VI}}$ & 0.25 & 62.2 & 164.63 & \\
\hline $\mathrm{Mg}^{\mathrm{II}}$ & 0.25 & 0.0 & 0.00 & \multirow{2}{*}{$\infty^{c}$} \\
\hline $\mathrm{Mo}^{\mathrm{VI}}$ & 0.25 & 49.6 & 98.26 & \\
\hline $\mathrm{Zn}^{\mathrm{II}}$ & 0.25 & 0.0 & 0.00 & \multirow{2}{*}{$\infty^{c}$} \\
\hline $\mathrm{Mo}^{\mathrm{VI}}$ & 0.25 & 48.0 & 92.50 & \\
\hline $\mathrm{Co}^{\mathrm{II}}$ & 0.34 & 32.6 & 48.47 & \multirow{2}{*}{2} \\
\hline $\mathrm{Mo}^{\mathrm{VI}}$ & 0.25 & 48.9 & 95.65 & \\
\hline $\mathrm{Fe}^{\mathrm{III}}$ & 2.58 & 8.9 & 9.80 & \multirow[b]{2}{*}{14} \\
\hline $\mathrm{Mo}^{\mathrm{VI}}$ & 0.25 & 57.5 & 135.25 & \\
\hline $\mathrm{Mn}^{\mathrm{II}}$ & 0.25 & 8.5 & 9.29 & \multirow{2}{*}{14} \\
\hline $\mathrm{Mo}^{\mathrm{VI}}$ & 0.25 & 55.9 & 126.72 & \\
\hline $\mathrm{U}^{\mathrm{VI}}$ & 0.50 & 5.9 & 6.25 & \multirow{2}{*}{14} \\
\hline $\mathrm{Mo}^{\mathrm{VI}}$ & 0.25 & 46.4 & 86.67 & \\
\hline $\mathrm{Mo}^{\mathrm{VId}}$ & 0.25 & 33.6 & 48.90 & - \\
\hline
\end{tabular}

${ }^{\mathrm{a}} \mathrm{K}_{\mathrm{d}}$ : Distribution coefficient; ${ }^{\mathrm{b}} \mathrm{k}$ : selectivity coefficients, ${ }^{\mathrm{c}} \mathrm{very}$ selectivity; ${ }^{\mathrm{d}}$ without foreign ions. 


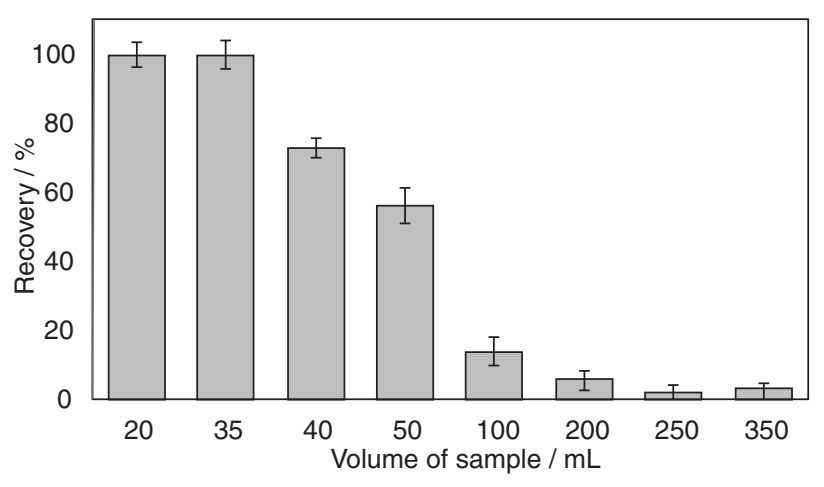

Figure 7. Effect of breakthrough volume on the adsorption of $\mathrm{Mo}^{\mathrm{VI}}$ on the IIP particles.

\section{Analytical performance of the method}

In order to evaluate the analytical applicability of the polymer particles, SPE method was applied to the extraction and determination of Mo in real water samples. The linearity of the method was evaluated utilizing standard samples at six different concentration levels of molybdenum ions from 10 to $1000 \mu \mathrm{g} \mathrm{L}{ }^{-1}$. A good linearity with squared correlation coefficient $\left(\mathrm{r}^{2}\right) 0.999$ was obtained for calibration curve. Three determination replicates of $500 \mu \mathrm{g} \mathrm{L} \mathrm{L}^{-1}$ molybdenum solutions resulted in a relative standard deviation of $4.6 \%$. The limits of detection (LODs) were calculated as the analytes concentration three times the standard deviation of the blank signal, after solid phase extraction of six blank sample with average intensity 10.7 in ICP-AES, divided by the slope of calibration curve $\left(8.66 \mu \mathrm{g} \mathrm{L}^{-1}\right)$. The enhancement factor, which was calculated from ratio of the slopes of calibration curves obtained with and without solid phase preconcentration method is 2.89 (the linearity of the calibration curve without preconcentration was 200-1000 $\mu \mathrm{g} \mathrm{L}^{-1}$ ). Tap water and Anzali lake water were tested to check the possible matrix effects and investigate the applicability of the method for real sample analysis. $72 \mathrm{~h}$ after sampling in polyethylene containers, the sample was filtered with filter paper ( 0.45 micron). The samples were divided into three aliquots and the analysis was carried out under the optimal conditions (Table 10). Since no Mo was found in the sample, the water samples were spiked with the Mo $\left(300 \mu \mathrm{g} \mathrm{L}^{-1}\right)$ to determine the relative recoveries of developed method. These results indicated the ability of the $\mathrm{Mo}^{\mathrm{VI}}$-imprinted polymer for selective SPE and determination of $\mathrm{Mo}^{\mathrm{VI}}$ in environmental water samples. A comparison between the proposed method and other SPE methods for the extraction and determination of Mo is presented in Table 11. The proposed method has a quantification limit is much less than references 24 and 27. Moreover, the preconcentration factor is equal with reference 28 but is less than reference 29 .

Table 10. Determination of molybdenum ions in real water samples

\begin{tabular}{lccc}
\hline Sample & $\begin{array}{c}\text { Molybdenum } \\
\text { concentration } \\
\text { added } /\left(\mu \mathrm{g} \mathrm{L}^{-1}\right)\end{array}$ & $\begin{array}{c}\text { Molybdenum } \\
\text { concentration } \\
\text { found } /\left(\mu \mathrm{g} \mathrm{L}^{-1}\right)\end{array}$ & Recovery / \% \\
\hline Anzali lake & 0.0 & not detected & - \\
Anzali lake & 300.0 & $298.8( \pm 3.9)^{\mathrm{a}}$ & 99.6 \\
Tap water & 300.0 & $274.9( \pm 4.3)^{\mathrm{a}}$ & 91.6 \\
\hline
\end{tabular}

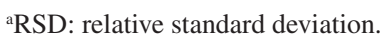

\section{Conclusions}

In the present study, $\mathrm{Mo}^{\mathrm{VI}}$ ions imprinted polymers was synthesized by thermal copolymerization of methacrylic acid and ethylene glycol dimethacrylate. For $\mathrm{Mo}^{\mathrm{VI}}-\mathrm{IIP}$ synthesis the ion pair between $\left(\mathrm{Mo}^{\mathrm{VI}}-\mathrm{SCN}^{-}\right)$and $\mathrm{NR}_{4}{ }^{+}$was

Table 11. Comparison of the proposed method with other methods for $\mathrm{Mo}^{\mathrm{VI}}$ determination in water samples

\begin{tabular}{|c|c|c|c|c|c|c|}
\hline Method & $\begin{array}{l}\text { Relative standard } \\
\text { deviation } / \%\end{array}$ & $\begin{array}{c}\text { Dynamic } \\
\text { linear range / } \\
\left(\mu \mathrm{g} \mathrm{L}^{-1}\right)\end{array}$ & $\begin{array}{l}\text { Limit of } \\
\text { detection / } \\
\left(\mu \mathrm{g} \mathrm{L}^{-1}\right)\end{array}$ & $\begin{array}{l}\text { Extraction } \\
\text { time / min }\end{array}$ & $\begin{array}{l}\text { Preconcentration } \\
\text { factor }\end{array}$ & Reference \\
\hline C-SPE (sample volume: $1 \mathrm{~mL}$ ) & $3.3(9.6)^{\mathrm{c}}$ & $500-12000$ & 200 & 5 & - & 27 \\
\hline $\begin{array}{l}\text { SPE-ICP-AES }{ }^{\text {b }} \text { (sample volume: } 50 \mathrm{~mL} \text {, } \\
\text { eluent: } 10 \mathrm{~mL} \mathrm{HNO}_{3} 0.5 \mathrm{~mol} \mathrm{~L}^{-1} \text { ) }\end{array}$ & $6.52(0.5)^{\mathrm{c}}$ & $\begin{array}{c}4.3 \\
\text { (quantification } \\
\text { limit) }\end{array}$ & 1.3 & 20 & 5 & 28 \\
\hline $\begin{array}{l}\text { Solid phase spectroscopy (sample volume: } \\
50 \mathrm{~mL} \text { ) }\end{array}$ & $1.7-2.6$ & $50-2500$ & 2 & 30 & - & 24 \\
\hline $\begin{array}{l}\text { SPE-ICP-AES }{ }^{\mathrm{b}}(\mathrm{sample} \text { volume: } 500 \mathrm{~mL} \text {, } \\
\text { eluent: } 5 \mathrm{~mL} \mathrm{HNO}_{3} 2 \mathrm{~mol} \mathrm{~L}^{-1} \text { ) }\end{array}$ & 3 & - & 0.17 & 30 & 100 & 29 \\
\hline $\begin{array}{l}\text { SPE-ICP-AES }{ }^{\mathrm{b}} \text { (sample volume: } 35 \mathrm{~mL} \text {, } \\
\text { eluent: } 7 \mathrm{~mL} \mathrm{HCl} 3 \mathrm{~mol} \mathrm{~L}^{-1} \text { ) }\end{array}$ & $4.6(0.5)^{\mathrm{c}}$ & $10-1000$ & 8.66 & 20 & 5 & this work \\
\hline
\end{tabular}

${ }^{\mathrm{a} C}$-SPE: Colorimetric solid phase extraction; ${ }^{\mathrm{b}} \mathrm{SPE}-\mathrm{ICP}-\mathrm{AES}$ : solid phase extraction-inductively coupled plasma- atomic emission spectrometry; ${ }^{\mathrm{C} S \mathrm{SD}}$ in $\mathrm{mg} \mathrm{L}^{-1}$. 
precipitated into aqueous sample and was dissolved into the acetonitrile as a porogen. Various parameters affecting the adsorption of Mo with polymer particles were evaluated and the best conditions for adsorption were found. The selectivity factor of polymer particles for $\mathrm{Mo}^{\mathrm{VI}}$ relative to $\mathrm{Cr}^{\mathrm{III}}, \mathrm{Pb}^{\mathrm{II}}, \mathrm{Cd}^{\mathrm{II}}, \mathrm{Mg}^{\mathrm{II}}, \mathrm{Zn}^{\mathrm{II}}, \mathrm{Co}^{\mathrm{II}}, \mathrm{Fe}^{\mathrm{III}}, \mathrm{Mn}^{\mathrm{II}}$ and $\mathrm{U}^{\mathrm{VI}}$ was determined. Due to the high selectivity shown by this new material toward molybdenum ions, it has been successfully employed for the selective separation and preconcentration of molybdenum ions from aqueous systems. In addition, the synthesized Mo-IIP is highly recommended for removing and separating Mo ions from uranium ions.

\section{Acknowledgments}

Financial support by Nuclear Fuel Cycle Research School, Nuclear Science \& Technology Research Institute (Tehran, Iran) during the period of this research is gratefully acknowledged.

\section{References}

1. Du, J. X.; Li, J. J.; Yang, L. J.; Lu, J. R.; Anal. Chim. Acta 2003, 481, 239.

2. Wang, D.; Aller, R. C.; Sanudo-Wilhelmyc, S. A.; Mar. Chem. 2009, 113, 250.

3. Schindelin, H.; Kisker, C.; Hilton, J.; Rajagopalan, K. V.; Rees, D. C.; Science 1996, 272, 1615.

4. Llamas, A.; Tejada-Jimenez, M.; Fernandez, E.; Galvan, A.; Metallomics 2011, 3, 578.

5. Marczenko, Z.; Lobinski, R.; Pure Appl. Chem. 1991, 63, 1627.

6. Haupt, K.; Mosbach, K.; Chem. Rev. 2000, 100, 2495.

7. Shea, K. J.; Trends Polym. Sci. 1994, 2, 166.

8. Wulff, G.; Angew Chem., Int. Ed. 1995, 34, 1812.

9. Takeuchi, T.; Haginaka, J.; J. Chromatogr. B: Biomed. Sci. Appl. 1999, 728, 1.

10. Segatelli, M. G.; Santos, V. S.; Presotto, A. B. T.; Yoshide, I. V. P.; Tarley, C. R. T.; React. Funct. Polym. 2010, 70, 325.

11. Dekova, I.; Karadjova, I.; Ivanov, I.; Georgieva, V.; Eutimova, B.; Georgiev, G.; Anal. Chim. Acta 2007, 584, 196.
12. Birlik, E.; Ersz, A.; Denizli, A.; Say, R.; Anal. Chim. Acta 2006, $565,145$.

13. Chang, X.; Jiang, N.; Zheng, H.; He, Q.; Hu, Z.; Zhai, Y.; Cui, Y.; Talanta 2007, 71, 38.

14. Mages, A. G.; Whitcombe, M. J.; Adv. Drug Delivery Rev. 2005 , $57,1742$.

15. Dakova, I.; Karadjova, I.; Georgieva, V. S.; Geargiev, G.; Talanta 2009, 78, 523.

16. Hande, P. E.; Samui, A. B.; Kulkarni, P. S.; Environ. Sci. Pollut. Res. 2015, 22, 7375.

17. Fu, J.; Chen, L.; Li, J.; Zhang, Z.; J. Mater. Chem. A 2015, 3, 13598.

18. Shirvani-Arani, S.; Ahmadi, J.; Bahrami-Samani, A.; GhannadiMaragheh, M.; Anal. Chim. Acta 2008, 623, 82.

19. Shakerian, F.; Dadfarnia, S.; Haji Shabani, A. M.; Food Chem. 2012, 134, 488.

20. Arab-zavar, M. H.; Chamsaz, M.; Zohuri, G.; J. Hazard. Mater. 2011, 185, 38.

21. Ren, Y.; Liu, P.; Ma, J.; Wen, Q.; Zhang, M.; Chem. Eng. J. 2013, 219, 286.

22. Saraji, M.; Yousefi, H.; J. Hazard. Mater. 2009, 167, 1152.

23. Andac, M.; Say, R.; Denizli, A.; J. Chromatogr. B: Anal. Technol. Biomed. Life Sci. 2004, 811, 119.

24. Kononova, O. N.; Kachin, S. V.; Chaikovskaya, A. E.; Kholmogorov, A. G.; Kalyakina, O. P.; Turk. J. Chem. 2004, 28, 193.

25. Deyhimi, F.; Arabieh, M.; Parvin, L.; Biocatal. Biotransform. 2006, 24, 263.

26. Deyhimi, F.; Ahangari, R. S.; Arabieh, M.; Parvin, L.; Int. J. Environ. Anal. Chem. 2006, 86, 1151.

27. Hayati, F.; Aksu, D.; Apak, R.; Boz, I.; Sens. Actuators, B 2009 , $141,491$.

28. Kalal, H. S.; Panahi, H. A.; Framarzi, N.; Moniri, E.; Naeemy, A.; Hoveidi, H.; Abhari, A.; Int. J. Environ. Sci. Technol. 2011, 8, 501.

29. Jimmy, C. Y.; Chan, S. M.; Chen, Z.; Anal. Bioanal. Chem. 2003, 376, 728 .

Submitted: September 17, 2015

Published online: January 28, 2016 